\title{
Neurofibromatosis Type 1: Piecing the Puzzle Together
}

\author{
Matthias M. Feldkamp, David H. Gutmann and Abhijit Guha.
}

\begin{abstract}
Neurofibromatosis type 1 (NF1) was first described in 1882 and is characterized by a diverse spectrum of clinical manifestations, including neurofibromas, café au lait spots, and Lisch nodules. NFl is also noted for the higher risk of associated malignancies, making it the most common tumour-predisposing disease in humans. Transmitted in an autosomal dominant manner, the $\mathrm{NFI}$ gene was cloned in 1990, and belongs to the family of tumour suppressor genes. Since then, there has been an explosion in our understanding of how the gene product, neurofibromin, functions in normal cellular physiology, and how its loss in NF1 relates to the wide spectrum of clinical findings, including NF1associated tumours. Neurofibromin is a major negative regulator of a key signal transduction pathway in cells, the Ras pathway, which transmits mitogenic signals to the nucleus. Loss of neurofibromin leads to increased levels of activated Ras (bound to GTP), and thus increased downstream mitogenic signaling. Our understanding of neurofibromin's role within cells has allowed for the development of pharmacological therapies which target the specific molecular abnormalities in NF1 tumours. These include the farnesyl transferase inhibitors, which inhibit the post-translational modification of Ras, and other agents which modulate Ras-mediated signaling pathways.
\end{abstract}

\begin{abstract}
RÉSUMÉ: Neurofibromatose de type I: la solution de l'énigme. La neurofibromatose de type I (NFI) a été décrite pour la première fois en 1882 . Elle se caractérise par un spectre varié de manifestations cliniques incluant des neurofibromes, des taches café au lait et des nodules de Lisch. On sait aussi que la NFI confère un risque plus élevé de cancers associés, ce qui en fait la maladie la plus fréquente associée à une prédisposition tumorale chez I'humain. Le gène de la NFI, cloné en 1990, est transmis sur le mode autosomal dominant et fait partie de la famille des gènes suppresseurs de tumeurs. Depuis ce temps, il y a eu une explosion dans notre compréhension de la façon dont le produit du gène, la neurofibromine, fonctionne dans les cellules physiologiquement normales et comment son absence dans la NFI mène à un large spectre de manifestations cliniques dont les tumeurs associées à la NFI. La neurofibromine est un régulateur négatif important d'une voie de transduction d'un signal clé dans les cellules, la voie Ras, qui transmet des signaux mitogènes au noyau. Le déficit en neurofibromine provoque des niveaux élevés de Ras activé (lié au GTP) et donc une augmentation du signal mitogène en aval. Notre compréhension du rôle de la neurofibromine dans les cellules a mené au développement de traitements pharmacologiques qui ciblent les anomalies moléculaires spécifiques aux tumeurs NFI. Parmi ceux-ci, signalons les inhibiteurs de la farnésyl transférase qui inhibent la modification post-traductionnelle de Ras et les autres agents qui modulent les voies de signalisation médiées par Ras.
\end{abstract}

Can. J. Neurol. Sci. 1998; 25: 181-191

\section{Neurofibromatosis type 1: clinical features}

The first published case of neurofibromatosis type 1 (NF1) was by von Recklinghausen in $1882,{ }^{\prime}$ whose name was associated with a diverse group of diseases characterized by multiple peripheral nerve tumours. Recent clinical and genetic understanding has led to the identification of two separate disease entities, termed NF1 (the subject of this paper) and NF2, both grouped together as von Recklinghausen disease in the past. $\mathrm{NFl}$ is the result of alterations of the $N F \mathrm{l}$ gene on chromosome $17 \mathrm{q}$, clinically characterized by peripheral neurofibromas, café au lait spots (CAL), Lisch nodules, and a myriad of other abnormalities. ${ }^{2}$ NF2 results from alterations of the $N F 2$ gene on chromosome $22,3,4$ and is characterized by bilateral vestibular schwannomas, meningiomas, ependymomas, and astrocytomas. ${ }^{5}$ Another point of confusion is the association of NF1 with the
Elephant Man Disease, in reference to the elephant man Joseph Merrick who lived from 1862-1890 and suffered from severe disfiguring skin lesions. However, recent re-evaluation of Joseph Merrick's medical history clearly shows that he did not suffer from NF1, but rather suffered from the rare Proteus syndrome. ${ }^{6}$

Program in Molecular Biology and Cancer, Samuel Lunenfeld Research Institute, Mount Sinai Hospital, Toronto, (M.M.F., A.G.); Division of Neurosurgery, The Toronto Hospital, and University of Toronto, Toronto, (M.M.F., A.G.): Departments of Neurology and Genetics, Washington University School of Medicine, St. Louis, U.S.A. (D.H.G.); Department of Surgical Oncology, Ontario Cancer Institute, (A.G.); Peripheral Nerve Unit, The Toronto Hospital, Toronto, Ontario, (A.G.).

RECEIVED AUGUST 22, 1997. ACCEPTED IN FINAL FORM DECEMBER 15, 1997.

Reprint requests to: Abhijit Guha, 2-415 McLaughlin Pavilion, The Toronto Hospital, Toronto Western Division, 399 Bathurst Street Toronto, Ontario, Canada M5T 2S8 
The hallmarks of NFI are the cutaneous neurofibromas, consisting of a mixture of Schwann cells, fibroblasts, and mast cells, ${ }^{7}$ which generally do not appear until adolescence. Therefore, other defining features arising earlier in childhood are often the first signs of NF1. These include CAL, which appear during the first year of life and are present in $95 \%$ of NF1 adults. ${ }^{8}$ Since $3 \mathrm{CAL}$ spots may be present in up to $25 \%$ of the normal population, ${ }^{9} 6$ or more CAL spots is considered suggestive of NFI. ${ }^{10}$ Freckling in non-sun-exposed regions of the body and Lisch nodules (pigmented hamartomas of melanocytic origin in the iris) are more specific and can be detected early in NFI patients. ${ }^{8.11}$ While these are the most common clinical signs of NF1, a large number of diverse cutaneous, osseous, hematologic, developmental, and nervous system abnormalities are often present. ${ }^{2}$ The number and severity of these clinical abnormalities is variable not only between members of different NF1 families, but between members of the same family, leading to occasional confusion in the clinical diagnosis. In an effort to standardize diagnostic criteria, which has tremendously helped both epidemiological and molecular studies on NF1, the National Institutes of Health set uniform diagnostic criteria for NF1, as well as a separate set of criteria for NF2 ${ }^{10}$ (Table). Despite recent advances in our understanding of the molecular basis of $\mathrm{NF}$, these clinical criteria continue to be the most reliable means for making the diagnosis. ${ }^{12}$

The two major life threatening complications of NFl are hypertension and cancer. ${ }^{13.14}$ Renal artery stenosis and pheochromocytoma, which occur at a higher frequency in NF1 patients, should be excluded as the cause for hypertension, although most hypertension is primary in nature. ${ }^{15}$ Malignancies other than neurofibromas and pheochromocytomas noted at a higher frequency in NF1 patients include malignant peripheral nerve sheath tumours (MPNST), astrocytomas (most notably optic gliomas), and chronic myeloid leukemias of childhood. ${ }^{16}$ In contrast, common adult malignancies such as lung, colon and breast cancers are not seen at higher frequency in NF1. ${ }^{17}$ Most $\mathrm{NF}$ l-related deaths are thus attributed to either hypertension or cancer. In a 12-year prospective population study in Göteborg, Sweden, 22 of 70 NF1 patients died, 10 from hypertension and 12 from malignancies. ${ }^{14}$ These NF1 patients thus demonstrated an age and sex-adjusted death rate 4.3 times that of the non-NF1 Swedish population. Nonetheless, the diagnosis of NF1 should not be routinely regarded as life threatening, with a majority of patients surviving well into their adulthood, with a mean survival age of 61.6 years in this study. ${ }^{14}$

\section{Genetics}

NFl has a birth incidence of 1:2500-1:3000, with a prevalence of 1:4000-1:5000. ${ }^{18}$ The Mendelian inheritance pattern of $\mathrm{NF} 1$ is autosomal dominant. ${ }^{19-21}$ Although case reports have suggested that NFl can skip generations, these cases likely represent mildly affected individuals. ${ }^{22}$ About $30-50 \%$ of NF1 patients represent de-novo germline mutations, ${ }^{2,20}$ implying an extremely high spontaneous mutation rate of the $N F I$ gene. This mutation rate has been estimated at 1 mutation per 10,000 alleles per generation, a rate 10-100 times higher than the usual mutation rate for a single locus. ${ }^{20.23,24}$ Such a high mutation rate may be related to the large size of the $N F I$ gene, as the similarly large Duchenne muscular dystrophy $(D M D)$ gene ${ }^{25}$ also demonstrates a mutation rate of $1 / 10,000$ alleles/generation. ${ }^{26}$ Howev-

\section{Table: Diagnostic Criteria for NF1. ${ }^{10}$}

The diagnostic criteria of the National Institutes of Health Consensus Conference on Neurofibromatosis (July, 1987) are met by an individual who demonstrates two or more of the following:

- 6 or more café au lait macules of over $5 \mathrm{~mm}$ in greatest diameter in prepubertal individuals and over $15 \mathrm{~mm}$ in greatest diameter in postpubertal individuals

- 2 or more neurofibromas of any type or one plexiform neurofibroma

- axillary or inguinal freckling

- optic glioma

- 2 or more Lisch nodules (iris hamartomas of melanotic origin)

- a distinctive osseous lesion such as sphenoid dysplasia or thinning of the long bone cortex with or without pseudoarthrosis

- a first-degree relative (parent, sibling, or offspring) with NF1 by the above criteria.

er, the size of the gene may not be the full explanation, as evidenced by a similar germ-line mutation rate of the much smaller $N F 2$ gene, which has a ten-fold lower birth incidence than NFI (1/33,000-40,000 live births). ${ }^{5}$ Germ-line mutations of the $N F I$ gene occur preferentially on the paternally-derived allele, ${ }^{26-29}$ which has also been noted in achondroplasia, Lesch-Nyhan syndrome, and hemophilia A. However, in each of the latter diseases the incidence of new mutations increases with parental age, ${ }^{29}$ implying that paternal bias is related to the high number of cell divisions which occurs during spermatogenesis, ${ }^{26.29}$ a pattern not seen in NF1.2,29 The phenomenon of genomic imprinting has been proposed as an alternate explanation for these preferential paternal allele mutations. ${ }^{27-31}$ Classical Mendelian genetics assumes that both alleles (maternal and paternal) of a gene participate equally in determining the phenotype of the offspring. The concept of genomic imprinting has thus been developed to explain situations where one allele is preferentially expressed over the other allele. Hence, genomic imprinting is an epigenetic phenomenon, in which non-genetic modifications of an allele result in altered expression and phenotype. A common mechanism resulting in genomic imprinting involves hypermethylation of the sperm genome; ${ }^{32.33}$ a hypermethylated gene is at higher risk for mutations through the spontaneous deamination of 5-methylcytosine (methylated cytosine nucleotides) to thymine. ${ }^{30}$ Methylation has also been proposed as a mechanism for gene silencing, in which either the maternally- or paternallyderived allele is active while the other allele does not contribute to gene expression. Methylation may thus explain why children of affected NF1 mothers (mutation of the maternal NFI allele with gene silencing of the paternal NFI allele by methylation) often demonstrate a more severe clinical manifestation than children of affected fathers (in which the mutated paternal allele may be silenced by methylation, allowing the non-mutated maternal allele to alone contribute to gene expression). ${ }^{34}$

In addition to the $N F I$ allele, some evidence exists that other genetic loci may also contribute to the phenotype of NFI patients. Analyses of monozygotic twins and more distantlyrelated family members with NFI demonstrate that monozygotic twins have very similar phenotypes, while non-twin siblings 
and more distantly-related family members (who presumably carry identical $N F I$ mutations) frequently exhibit very different phenotypes. ${ }^{35}$ Such a pattern is suggestive of polygenic inheritance, and implies that the expression or mutation of non- $N F I$ alleles is important in determining the phenotype of NFl patients. ${ }^{35}$

\section{Cloning the NF1 gene}

The uniform NIH clinical diagnostic criteria led to the identification of a relatively homogenous cohort of patients and families with $\mathrm{NFI},{ }^{10}$ which in turn played a pivotal role in the ultimate identification of the responsible gene. Restriction fragment length polymorphism (RFLP) and linkage studies of NFl families suggested the pericentromeric region of chromosome 17 as the likeliest site for the NF1 gene. ${ }^{36-39}$ Two NFI families with balanced translocations involving $17 \mathrm{q}(\mathrm{t}(1 ; 17)$ and $\mathrm{t}(17 ; 22)),{ }^{40,41}$ helped map the $N F I$ gene to chromosome $17 \mathrm{q} 11.2,{ }^{42}$ a region which harboured three candidate genes. ${ }^{43}$ Mutations of the first candidate gene, EVI2A, the human homologue of a mouse gene implicated in retrovirus-induced murine myeloid tumours, were not found in any NFl patients, thus ruling it out. ${ }^{44}$ The second candidate gene was $E V I 2 B$, also a human homologue of a murine gene implicated in retroviral insertions, however, it also failed to demonstrate mutations in NF1 patients. ${ }^{45}$ The $O M G P$ gene, encoding oligodendrocytemyelin glycoprotein and expressed only in oligodendrocytes and Schwann cells, was the third candidate gene, ${ }^{46}$ but also was found not to be mutated in NF1 patients. Subsequent analysis has shown that these three genes are encoded within the large authentic $\mathrm{NFI}$ gene, ${ }^{47}$ but transcribed off the opposite strand, a phenomenon known as "nested genes". The contribution of these three nested genes to the NF1 clinical phenotype, if any, is not known.

The authentic $N F I$ gene was cloned in 1990, largely with the help of probes that extended well beyond the previously reported translocation breakpoints (Figure 1). ${ }^{18,45,48,49}$ Most of the $N F I$ gene maps to a NotI restriction fragment of approximately 350 kilobases $(\mathrm{kb})$ in size (all but $15 \mathrm{~kb}$ of this fragment is made up of $N F /$ genomic DNA), while exon 1 and the 5' untranslated region maps to an adjacent $120 \mathrm{~kb}$ NotI fragment (Figure 1). ${ }^{50}$ Due to the evolution of the exon numbering scheme, the exon containing the 3' stop codon is numbered exon 49 , even though the entire gene consists of 59 exons. ${ }^{50}$ The second-largest intron is intron $27 \mathrm{~b}(45-50 \mathrm{~kb})$, which contains the three nested genes $O M P G, E V 12 A$, and $E V I 2 B$ described above. ${ }^{50}$ Exons $21-27$ a encode a 360 amino acid domain in the protein product which demonstrates homology with GTPase-activating proteins, and is termed the GAP-related domain (GRD). ${ }^{50}$ The 5 ' promoter region contains a cAMP response element (CRE), AP2 consensus binding sites, and a serum response element (SRE). ${ }^{51}$ The cDNA is 8454 nucleotide base pairs (bp) in length, ${ }^{18}$ with two messenger RNA (mRNA) transcripts ( 11 and $13 \mathrm{~kb}$ ), which differ in the length of their 3 ' untranslated region. ${ }^{50.52}$

\section{Expression of neurofibromin}

Neurofibromin is composed of 2818 amino acids with a molecular weight of 220 kilo-Daltons (kDa). ${ }^{18.53 .54}$ While $N F 1$ mRNA is detectable in most tissues, the expression of the neurofibromin protein is more tightly regulated, with highest levels found in neurons, oligodendrocytes, non-myelinated Schwann

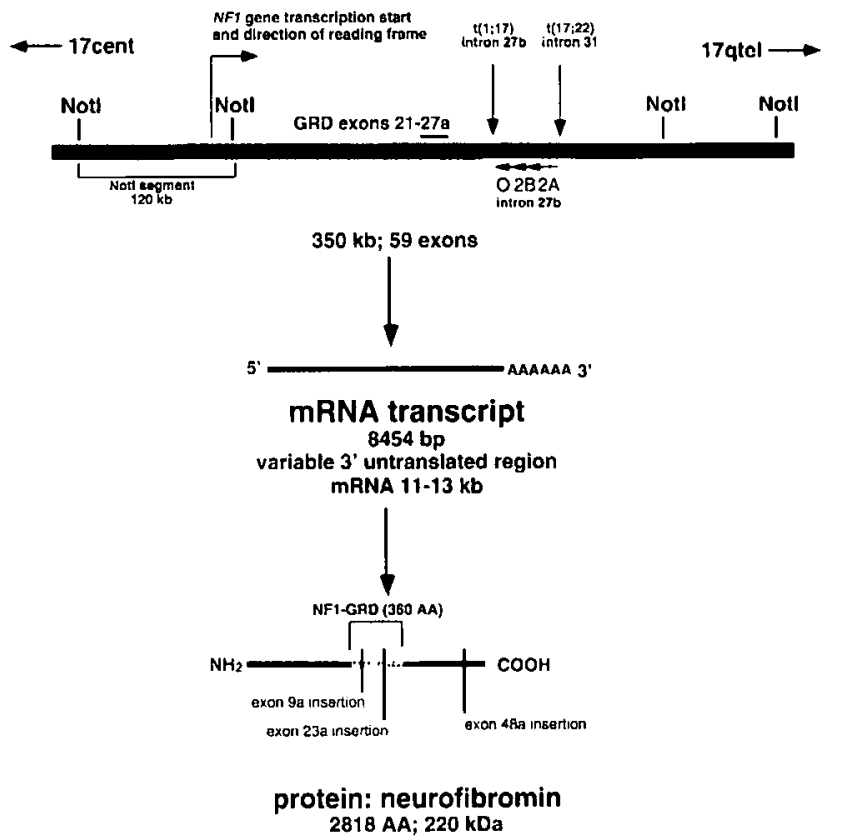

Figure 1: Schematic representation of the NFI gene, its mRNA transcript, and its protein product, neurofibromin. The NFI gene is a large gene of $350 \mathrm{~kb}$. Its cloning in 1990 was facilitated by the discovery of two NFl patients with balanced translocations involving chromosome $17 q(t(1 ; 17)$ and $t(17 ; 22))$. Three attempts at identifying the $\mathrm{NFI}$ gene failed to discover the true NFl gene, instead discovering the three nested genes OMGP (O), EVI2A (2A), and EV12B (2B), which are transcribed off the opposite strand. The $m R N A$ transcript is $11-13 \mathrm{~kb}$ long, depending on the length of the 3' untranslated region. Neurofibromin is a large protein, with a molecular weight of $220 \mathrm{kDa}$. The indicated size of the NFI mRNA ( $8454 \mathrm{bp})$ and resultant protein (2818 amino acids) do not include the various tissue- and development-specific isoforms, which arise from the insertion of alternatively spliced exons $9 a, 23 a$, and/or $48 a$.

cells, adrenal medulla, leukocytes and testis. ${ }^{55.56}$ In comparison, it is expressed in low amounts in adult astrocytes, myelinated Schwann cells, lung and kidney. ${ }^{55.56}$ Four neurofibromin isoforms, which differ in their developmental and tissue expression, have been identified due to insertions into exons $23 \mathrm{a}, 48 \mathrm{a}$, and $9 \mathrm{a}$ (Figure 1). Type 1 neurofibromin was the original isoform isolated and lacks any of these insertions. Type 2 isoform has an insertion of 63 nucleotides ( 21 amino acids) in exon 23a within the NF1-GRD, ${ }^{57.58}$ which results in a 10 -fold lower RasGAP activity and lower tubulin binding capacity. ${ }^{56.57}$ Type I neurofibromin is the predominant isoform expressed in neurons of the CNS (cerebellum, cerebral hemispheres, and brainstem) and dorsal root ganglia, while the Type 2 isoform is predominantly expressed in tissues derived from the neural crest such as Schwann cells and adrenal medullary cells, in addition to glia and anterior horn cells of the adult spinal cord. ${ }^{56.59}$

Insertion of 54 nucleotides ( 18 amino acids) in exon 48 a near the extreme carboxyl terminus results in the Type 3 isoform, ${ }^{60}$ which is almost exclusively expressed in skeletal, cardiac, and smooth muscle, with little or no expression in brain, spleen or kidney. ${ }^{61}$ This isoform is highly expressed during embryogenesis and declines shortly after birth, suggesting a role in muscle development. ${ }^{61}$ Insertion of 30 nucleotides (10 amino acids) in 
exon 9a, within the NF1-GRD yields the Type 4 isoform, which is only expressed in neurons of the CNS, and not in neural crest derived tissues ${ }^{62}$ or in glial cells. ${ }^{63}$ Within the CNS, there is regional variation in the expression of the Type 4 isoform, which also likely plays a role in neuronal development, with increased expression during late embryogenesis. ${ }^{63}$ In addition, this isoform is highly expressed in medulloblastomas and oligodendrogliomas, while it is found in low levels in astrocytomas, meningiomas, and ependymomas. ${ }^{62,64}$

\section{Neurofibromin function: negative regulator of Ras}

At the time of its cloning, the function of the NFI gene product, since termed neurofibromin, was unknown. Homology screening was undertaken to identify genes with known function that resembled the $N F I$ gene, and that would offer clues as to the function of the neurofibromin protein. A small region in the central portion of neurofibromin demonstrated $30 \%$ homology with members of the Ras-GTPase Activating Protein (Ras-GAP) family, which includes three other mammalian proteins ( $\mathrm{pl} 20$ GAP, GAPI ${ }^{m}$, and GAPI ${ }^{\text {PABPP }}$ ) plus two yeast proteins (Iral and Ira2). ${ }^{47.65-67}$ Members of the Ras-GAP family are negative regulators of the key signal transduction protein Ras, as discussed below. ${ }^{47.67-74}$

Ras is a $21 \mathrm{kDa}$ intracellular protein that is involved in the transmission of signals from a variety of upstream activators such as growth factor receptors, to a large number of downstream signaling molecules which eventually alter gene function in the nucleus. Ras is a member of the small $G$ protein family, characterized by being bound to GDP in the basal inactive state, and being activated to the GTP bound state by guanine nucleotide exchange factors, in particular Sos. ${ }^{69.70 .75-79}$ As schematized in Figure 2, activated growth factors such as platelet-derived growth factor (PDGF) and epidermal growth factor (EGF) bind and activate their cognate receptor, with receptor activation characterized by autophosphorylation of specific tyrosine residues on the intracellular domain of the receptor. Specific phosphotyrosine residues on the activated receptor are recognized by protein modules, such as $\mathrm{SH} 2$ (src homology-2) and PTB (Phosphotyrosine Binding) domains, on intracellular signaling proteins such as Grb2 and Shc. ${ }^{75,80,81}$ Grb2 and Shc, through their interactions with the activated receptors in turn recruit other proteins such as Sos to the receptor in proximity to its substrate (inactive $\operatorname{Ras}^{\bullet} \mathrm{GDP}$ ) at the cell surface. ${ }^{76}$ Sos exchanges Ras-bound GDP for GTP, resulting in activation of Ras and initiation of downstream signaling pathways, in particular the mitogenic cascade through Raf, MAPKK (mitogen-activated protein kinase kinase, also known as MEK or ERK kinase), and MAPK (mitogen-activated protein kinase, also known as extracellular signal related kinase or ERK) (Figure 2).

The importance of activation of the Ras pathway and subsequently Raf-MAPKK-MAPK leading to mitogenic signals, is exemplified by oncogenic activating mutations of Ras being found in approximately $30 \%$ of all human cancers. ${ }^{71,82.83} \mathrm{In}$ addition to oncogenic mutations, functional up-regulation of the Ras pathway can also be achieved by increased stimulation from upstream activators of Ras (i.e., signals from activated receptors) or decreased inhibitors of the Ras pathway. With regards to the latter mechanism, activated Ras $\bullet$ GTP is slowly hydrolyzed to GDP by intrinsic GTPase activity in native Ras, a process that is rapidly catalyzed by Ras-GAPs, including neurofibromin. ${ }^{47,67-74}$ Several pieces of evidence demonstrate that neurofibromin is an important mammalian Ras-GAP, other than the homology of the GRD domain with other known Ras-GAPs (reviewed above): 1) Expression of only the NF1-GRD portion is capable of hydrolyzing Ras ${ }^{\bullet}$ GTP to Ras ${ }^{\circ}$ GDP in vitro ${ }^{84}$ and in vivo. ${ }^{85}$ 2) Expression of the NF1-GRD is able to rescue Ira1 and Ira2 deficient yeast mutants. ${ }^{86}$ 3) Overexpression of neurofibromin or the GRD portion suppresses oncogenic Ras transformed cells. ${ }^{87-91}$ Another pivotal discovery that supported the Ras-GAP function of neurofibromin was the demonstration that neurofibrosarcoma (malignant peripheral nerve sheath tumour) cell lines established from NF1 patients not only lacked neurofibromin expression but had elevated levels of activated Ras ${ }^{\bullet}$ GTP ${ }^{88.89}$ We have recently adapted a luciferase-based enzymatic assay to quantitate the levels of Ras $\cdot G T P$ in actual tissue specimens from NF1 patients. We have confirmed that in NFl-associated malignant peripheral nerve sheath tumours (MPNST), neurofibromin expression is absent and that levels of Ras ${ }^{\circ}$ GTP are substantially elevated. ${ }^{73}$ Our studies demonstrate that Ras ${ }^{\bullet}$ GTP levels are approximately four and fifteen times higher in NF1-associated neurofibromas and MPNSTs respectively, compared to schwannomas from non-NF1 patients. ${ }^{73.92}$

\section{Neurofibromin function: additional functions}

While it is clear that neurofibromin acts as a Ras-GAP, there is also a growing body of evidence that this is not its only function. First, in melanoma and neuroblastoma cell lines levels of activated Ras $\bullet$ GTP are not elevated, despite complete absence of neurofibromin. ${ }^{93}$ Second, overexpression of neurofibromin in Ras transformed cells revert the tumourigenic phenotype, even though the oncogenic Ras mutant is insensitive to neurofibromin's GTPase activity. ${ }^{90}$ Since oncogenic Ras mutants, like normal Ras, can bind neurofibromin (through interactions with the NFI-GRD region) but are resistant to its Ras-GAP activity, it would suggest that in addition to its Ras-GAP role neurofibromin has other tumour suppressor functions. In fact, overexpression of just the NF1-GRD region in these Ras-transformed cells is equally successful in reverting the malignant phenotype..$^{94}$ It is not clear what these non Ras-GAP related tumour suppressor functions of neurofibromin entail. Neurofibromin does associate with microtubules, ${ }^{95-97}$ suggesting a potential role in linking activated Ras.GTP to changes in cellular structure. Additional functions may relate to neurofibromin's six potential serine/threonine cAMP dependent protein kinase recognition sites and one potential tyrosine phosphorylation site, which are phosphorylated in response to PDGF or EGF. ${ }^{18.98,99}$ Phosphorylation of these residues however has no effect on neurofibromin's Ras-GAP activity. ${ }^{100}$

The presence of phosphorylation sites as well as neurofibromin's interactions with the cytoskeleton suggest that it is a highly regulated protein. We have investigated how activation of Ras might affect the expression of neurofibromin, and demonstrated that activated Ras $\bullet$ GTP transcriptionally upregulates neurofibromin expression. ${ }^{101}$ For instance, human malignant astrocytoma cell lines have increased levels of Ras ${ }^{\text {GTP }}$ due to stimulation from growth factor receptors (A. Guha, unpublished results), with abundant neurofibromin expression. Inhibiting Ras $\bullet$ GTP levels in these cells, using dominant negative Ras mutants, reduced NFI mRNA and protein 


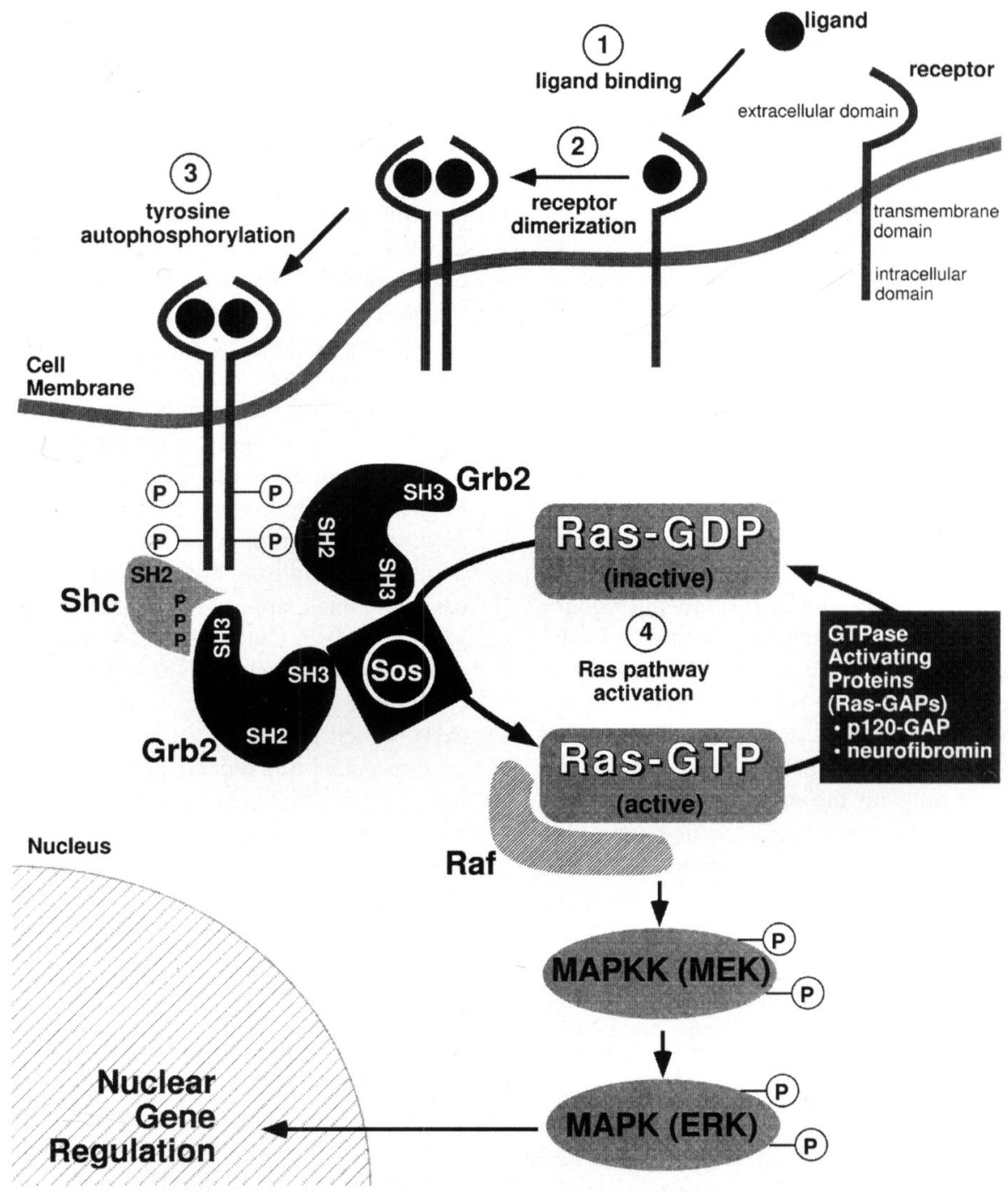

Figure 2: Schematic representation of the Ras-Raf-MAPK mitogenic signaling pathway. This cascade is activated in normal cells when ligand (a growth factor such as platelet-derived growth factor) binds its cognate surface receptor (STEP 1). Ligand:receptor interaction results in receptor dimerization (STEP 2), resulting in transautophosphorylation of tyrosine residues on the intracellular domain of the receptor (STEP 3). This allows signaling molecules with SH2 domains (Shc, Grb2 or the Shc:Grb2 complex) to interact with the phosphotyrosine residues, bringing the nucleotide exchange factor Sos in proximity to the cell surface, where it exchanges GDP with GTP, activating Ras. Raf interacts with activated Ras ${ }^{G T P}$, phosphorylating MAPKK, which subsequently phosphorylates MAPK. MAPK translocates to the nucleus where it participates with other molecules in activating the transcription of the transcription factors fos and jun, resulting in the increased transcription of genes involved in cell division and other functions (STEP 4).

expression. ${ }^{101}$ Neurofibromin expression is also increased in reactive astrocytes surrounding regions of focal ischemia, ${ }^{102}$ and in juvenile pilocytic astrocytomas. ${ }^{64}$ These results suggest a physiological negative feedback response, whereby activation of the Ras pathway increases neurofibromin expression in order to downregulate the Ras pathway.

\section{Neurofibromin as a tumour suppressor gene}

The concept of the "two hit" hypothesis in tumour suppressor genes (TSG) in familial cancer syndromes developed from the work of Knudson in the molecular pathogenesis of retinoblastoma. ${ }^{103}$ The first hit involves a germ-line loss of function in one allele present in all cells, with the second hit being a somatic loss of function of the remaining allele in selected cells leading to tumour formation. NF1 patients bear a germ-line loss of function in one $N F I$ allele which is either inherited or a de-novo mutation as previously discussed, with loss of function in the second allele resulting in complete absence of neurofibromin expression and the genesis of tumours. There is evidence that this model holds true for a variety of NFl-associated tumours, including benign neurofibromas, ${ }^{28.73}$ pheochromocytomas, ${ }^{104-106}$ malignant myeloid disorders, ${ }^{16}$ and MPNSTs. ${ }^{73.92 .107 .108}$

Further evidence to support the hypothesis that $N F 1$ acts as a TSG comes from gene knockout studies, in which heterozygous 
$N F 1+/-$ mice possess a single functional $N F 1$ allele. ${ }^{109}$ While the classical cutaneous and ocular features of NFI were not detected, $75 \%$ of these mice succumbed to tumours compared to $15 \%$ in a matched set of wild type animals. Many of the tumours encountered (such as lymphoma) are tumours often seen in older wild-type mice, but in the heterozygous knockout mice these tumours appeared earlier and at a higher frequency. Other tumours identified in the heterozygous mice (particularly pheochromocytoma and myeloid leukemia) are rare in wild-type animals, but are characteristic tumours found at higher frequency in NFl patients. It is significant to note that all NFl-like tumours (pheochromocytomas and myeloid leukemias) in the mice demonstrated loss of the second $N F I$ allele, consistent with the Knudson hypothesis. ${ }^{109}$ The importance of neurofibromin in cellular growth and differentiation was exemplified by the homozygous $N F 1$-/- knockout mice, which are embryonically lethal between days 12.5 and 14 of gestation. ${ }^{109,110}$ Surprisingly, the cause of death in all embryos examined was severe cardiac vessel developmental anomalies, notably a double outlet right ventricle in which the aorta and pulmonary artery are joined, which is not a characteristic feature of NF1 patients. ${ }^{109}$ The cardiac anomalies are however not surprising, as neural crest-derived cells contribute to the development of the great vessels. ${ }^{11}$ Additional anomalies discovered in some of these homozygous knockout embryos include liver and skeletal muscle hypoplasia (consistent with the proposed role for exon 48a-containing neurofibromin isoforms in muscle development), delayed renal development, hyperplasia of the prevertebral and paravertebral sympathetic ganglia, as well as hyperplasia of the cells lining the aorta and pulmonary artery. ${ }^{109,110}$

The creation of NFI -/- knockout mice 109.110 has been exploited in gaining further insights into the functions of neurofibromin. Sensory neurons of the trigeminal and dorsal root ganglia derived from wild-type mouse embryos are dependent on the neurotrophic factor nerve growth factor (NGF) for survival, while nodose ganglion sensory neurons are dependent on brain-derived growth factor (BDNF) for their survival in cell culture. Sensory cells derived from NFI -/- embryos on the other hand are capable of surviving and extending neuronal processes in the absence of NGF or BDNF. ${ }^{112}$ This extends previous studies in which activated Ras ${ }^{-G T P}$ was able to mimic the survival-promoting effects of neurotrophic factors, ${ }^{113}$ and identifies neurofibromin as a major regulator of neurotrophin- and Rasmediated neuronal survival. ${ }^{\prime 2}$ Studies on NF1 -/- Schwann cells confirmed that neurofibromin is a major negative regulator of Ras in these cells, as they demonstrate elevated levels of Ras ${ }^{\bullet}$ GTP. ${ }^{\prime \prime 4}$ Furthermore, these Schwann cells take on morphological characteristics of Ras transformed cells, and are similar to Schwann cells stimulated with trophic factors such as the neuregulins, which activate the Ras pathway through activation of their receptors. ${ }^{114.115}$ In contrast to Schwann cells, fibroblasts from the NF1 -/- mice did not demonstrate elevated levels of Ras ${ }^{\bullet} \mathrm{GTP}$, in support of other experimental data previously discussed that the importance of neurofibromin as a Ras-GAP differs between cell types, with perhaps Ras activity in some cells predominantly regulated by other Ras-GAPs such as pl20GAP. ${ }^{114}$

\section{Malignant transformation of neurofibromas in NF1 patients}

Benign neurofibromas consist of a heterogeneous population of Schwann cells, mast cells, fibroblasts, neuronal axons, perineural cells and endothelial cells. ${ }^{2,116}$ The dermal neurofibromas are generally little more than a cosmetic problem while the larger plexiform neurofibromas, though histologically benign, arise in nerve plexuses and present with neurological deficits. Of greater significance, the plexiform neurofibromas have a $3-4.6 \%$ risk for malignant transformation, ${ }^{13,117}$ a figure much lower than previously speculated, but one which is much higher than the less than $1 \%$ risk of malignant transformation in a non-NF1 neurofibroma. ${ }^{118,119}$ Knowledge of these risks for malignant transformation vs. the surgical risks have to be considered for the proper management of NFl patients presenting with peripheral nerve tumours.

Although activating mutations of Ras are not found in benign or malignant peripheral nerve tumours, several other TSGs have been implicated in the pathogenesis of MPNSTs (Figure 3). Loss or mutations of the $p 53$ gene on chromosome $17 \mathrm{p}$ has been discovered in numerous sporadic and NFI-associated MPNSTs. ${ }^{120-125}$ Mutations of the retinoblastoma $(R b)$ gene, found in osteosarcomas, appear not to play a role in the pathogenesis of MPNSTs. ${ }^{126-128}$ Cytogenetic analysis suggests that hotspots for additional mutations in NF1-associated MPNSTs are located on chromosomes $1,11,12,14$, and $22 .{ }^{129}$ Microsatellite instability (MI), which represents expansions or compressions of di-, tri-, or tetra-nucleotide repeats in a genetic locus, are a frequent finding in NF1-associated neurofibromas, with $8 / 16$ patients manifesting alterations at one or more microsatellite loci within the tumour. ${ }^{130}$ However, the definition of what is significant MI is evolving, with the current accepted criterion requiring involvement of at least two or more loci. ${ }^{131}$ When this more stringent criterion is applied to NF1-associated MPNSTs, only 1/16 patients truly demonstrates MI. ${ }^{132}$

\section{Applying our understanding of molecular biology to improving the diagnosis of NF1}

Despite the identification of the $N F 1$ gene, it has been difficult to apply genetic techniques to the diagnosis of NFl. NF1 patients frequently request prenatal genetic testing to rule out transmission of the defective $N F 1$ gene to their child. Similarly, NFl patients who do not desire prenatal testing may still wish to screen their young child for the defective allele, as many phenotypic manifestations of NF1 do not appear until late childhood or early adolescence. Both of these situations lend themselves well to genetic testing, provided that the family $N F J$ mutation is known. As the child can be expected to carry the same mutation as the affected parent, genetic testing can be very focussed and specific. In situations where the $N F I$ mutation has not been characterized, genetic testing would imply a far more general screening of the entire gene. Such testing would thus be identical to genetic screening techniques applied to patients without a family history of NF1. A large variety of mutations have been discovered in the $N F I$ gene in NFl patients, including single base mutations, deletions of various sizes including the entire gene, insertions, splicing errors, and translocations. ${ }^{50.133}$ Only one mutation has been found to be relatively common in NF1 patients, but this R1947X mutation still only accounts for at most $8 \%$ of mutations among Japanese patients and at most $2 \%$ of NF1 mutations among Caucasians. ${ }^{134}$ Hence, no single specific alteration in high frequency (mutational hotspot) or significant genotype-phenotype correlation (where one can predict the 


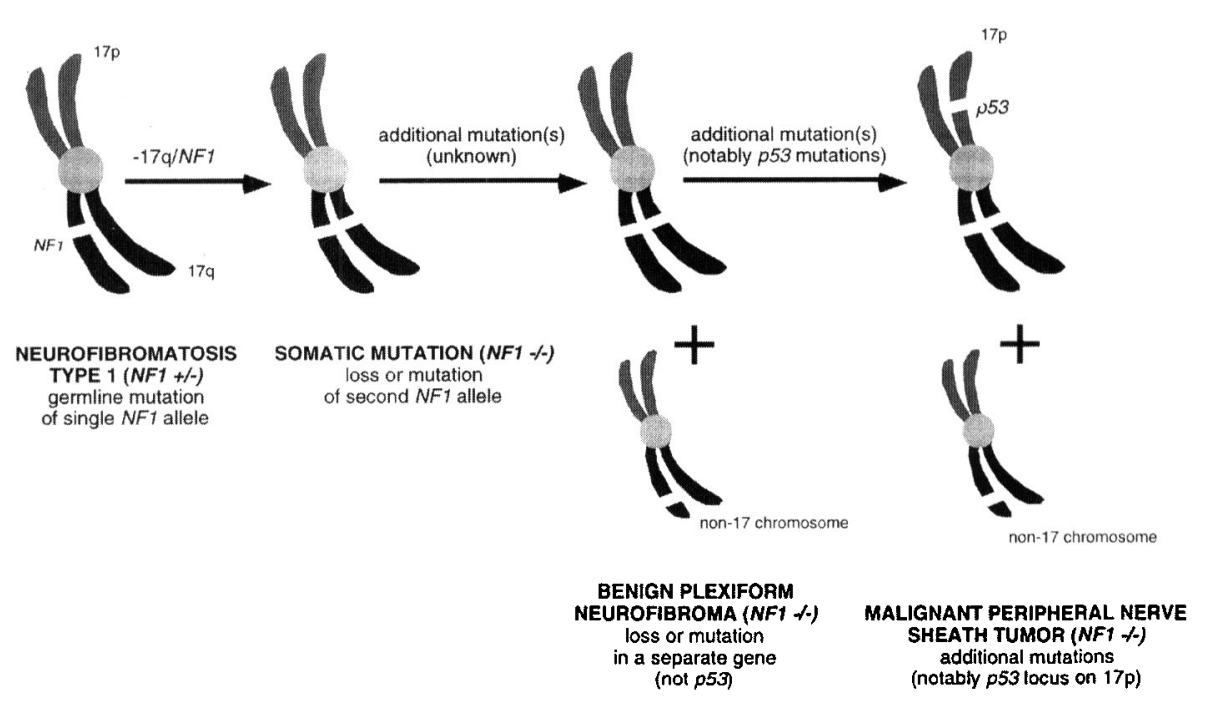

Figure 3: Schematic representation of the proposed molecular pathogenesis of benign and malignant NFI-associated peripheral nerve tumours. One allele of the NFI gene on $17 q$ is mutated in all cells in NFI patients (germline mutation). Subsequent mutation or loss of the second NFI allele in an individual cell (somatic mutation) appears insufficient to result in the formation of a benign neurofibroma, with mutations in one or more additional genes required for the development of the benign NF1-associated neurofibromas. Further additional genetic mutations (such as in the p53 locus on $17 p$ ) result in the malignant transformation of a benign plexiform neurofibroma into a malignant peripheral nerve sheath tumour. Dermal neurofibromas do not appear to be subject to the risk of malignant transformation.

clinical presentation based on the location and type of mutation) has been identified. ${ }^{133}$ The lack of mutational hot spots, large size of the $\mathrm{NFI}$ gene, high spontaneous mutation rate and lack of genotype-phenotype correlation have all contributed to the hurdles which still make routine genetic screening impractical. ${ }^{12.135-137}$ The NIH clinical diagnostic criteria remains the best method of detecting new patients with NF1 (see Table).

\section{Applying our understanding of molecular biology to improving the clinical management of NF1}

Although our understanding of the molecular events in NFl have not displaced the NIH clinical criteria in making the diagnosis of NFl (see Table), our expanding understanding of these molecular events has resulted in new efforts to treat the variety of symptoms and tumours associated with this syndrome. Surgery is not always an option for deep-seated tumours or in eloquent regions of the central or peripheral nervous system. Even when surgery is performed, patients with MPNST frequently succumb not to their primary tumour but to metastases (L. Angelov, R. Bell, and A. Guha, unpublished observations), and all patients dying of malignancy in the Swedish prospective study harboured metastases at the time of death. ${ }^{14}$ In particular, the pivotal role that neurofibromin plays in the regulation of the Ras pathway suggests that novel pharmacological inhibitors of Ras pathway activators may hold great promise for managing a number of NFl-associated benign or malignant lesions.

Ras pathway activation has been implicated in $30 \%$ of human malignancies, on the basis of oncogenic point mutations in $R a s .^{71,82,83}$ Many pharmaceutical companies and academic research groups have thus developed inhibitors of Ras or of proteins in the Ras-Raf-MAPK pathway. In particular, farnesyl transferase inhibitors (FTIs) have been developed which inhibit the first critical step (farnesylation) in the post-translational modification of Ras, a step which is vital for Ras to be recruited to the inner cell membrane where it may be activated. ${ }^{138}$ This post-translational modification is catalyzed by the enzyme farnesyl transferase (FTase), and involves the transfer of a 15-carbon trans,trans-farnesyl moiety from farnesyl pyrophosphate (FPP) to the cysteine residue on the CAAX ( $\mathrm{C}=$ cysteine, $\mathrm{A}=$ aliphatic amino acid, $\mathrm{X}=$ other amino acid) motif at the $\mathrm{C}$-terminal of Ras. This first step is absolutely essential for Ras to become activated within the cell, while subsequent steps are not critical $^{139}$ (Figure 4). Although many other cellular proteins in addition to Ras are farnesylated, no adverse effects have been noted in experimental use of these agents in cell culture and animal models of human tumours bearing oncogenic Ras mutations. ${ }^{140}$

However, most studies to date have involved models of human cancer in which oncogenic Ras mutations resulted in constitutive activation of Ras, as demonstrated by elevated levels of $\operatorname{Ras}^{\bullet}$ GTP. NF1 patients do not harbour oncogenic mutations of Ras, and yet the downregulation of activated Ras•GTP through hydrolysis of GTP to GDP is slowed in the absence of neurofibromin. We had thus hypothesized that Ras•GTP levels would be elevated in MPNSTs in NFl patients. We have confirmed that levels of Ras ${ }^{\bullet} \mathrm{GTP}$ are substantially elevated in NFl associated MPNSTs, ${ }^{73}$ with Ras.GTP levels being approximately fifteen times higher in NFl-associated MPNSTs than in non-NF1 schwannomas. ${ }^{73,92}$ Hence, NF1-associated MPNSTs demonstrate activation of the Ras pathway, providing additional evidence to support a beneficial effect of FTIs in the management of NF1. Indeed, FTIs have been shown to inhibit the proliferation of the human MPNST cell line NF188-14 in tissue culture experiments. ${ }^{141}$ 


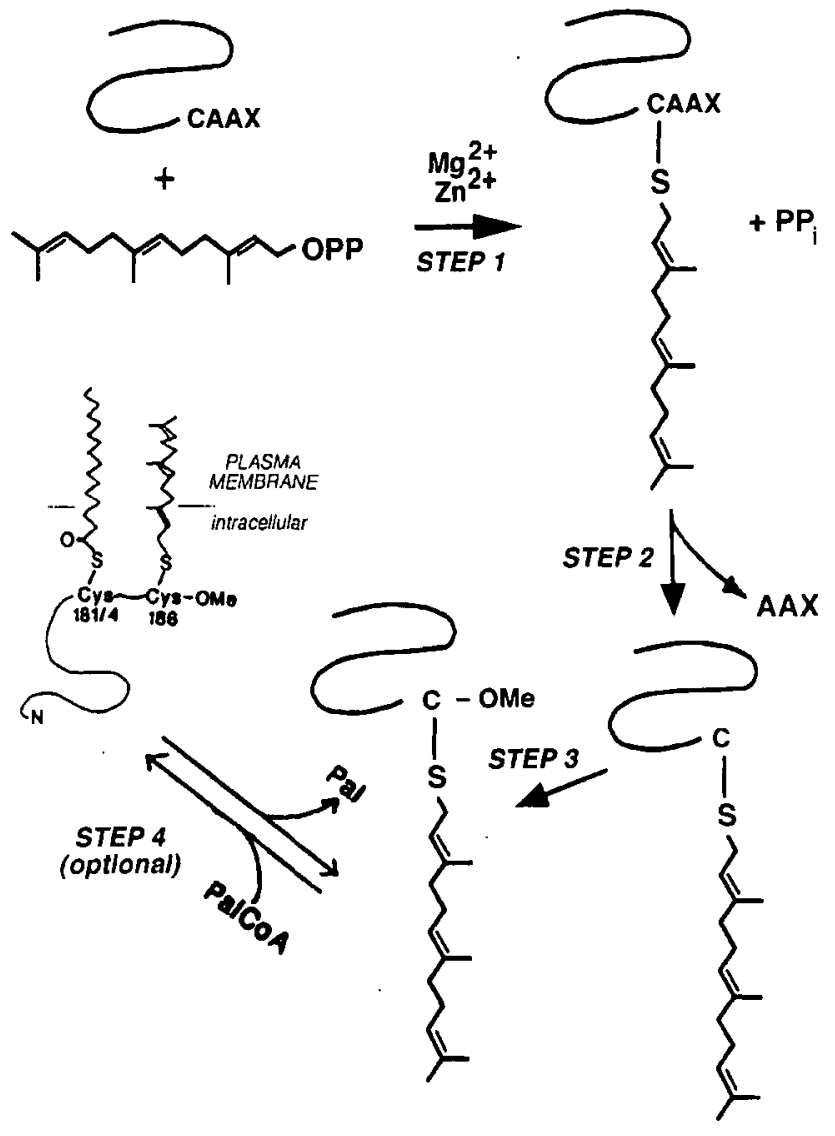

Figure 4: The post-translational modification of Ras has been targeted in the pharmacological inhibition of Ras pathway activation. Ras undergoes three or four post-translational modifications. The first step, catalyzed by the enzyme farnesyl transferase (FTase), involves the transfer of a 15-carbon trans,trans-farnesyl moiety from farnesyl pyrophosphate (FPP) to the cysteine residue on the CAAX $(C=c y s-$ teine, $A=$ aliphatic amino acid, $\mathrm{X}=$ other amino acid) motif at the $C$ terminal of Ras; this first step is absolutely critical for normal Ras functioning. Subsequent steps are less critical, and these include the cleavage of the terminal three AAX peptides, carboxyl-methylation of the now $C$-terminal, farnesylated cysteine residue and optional palmitoylation at cysteine residues upstream of the $C$-terminal cysteine.

Additional compounds targeting the Ras pathway are not as well developed presently, but include inhibitors of MEK which is involved in mitogenic signaling downstream of Ras in the RasRaf-MAPK cascade ${ }^{142}$ (Figure 2). While such pharmacological manipulations of the Ras pathway are still many years away from routine clinical use, they represent the progress that can be made in clinical treatment based on a solid understanding of basic cellular physiology and of the molecular mechanisms which result in individual disease processes. Future therapy tailored more specifically to the management of NF1 will benefit from further study and understanding of the role that neurofibromin plays in cells, in particular in its non-Ras-GAP functions. Additionally, the clinical management of NF1 will benefit from progress made in our understanding of other aspects of cellular physiology and gene regulation, as activity in a host of other cellular pathways likely impacts on the function of neu- rofibromin, through positive and negative regulatory loops. We can thus look upon the future with optimism in our goal of developing and implementing novel, effective, and safe therapeutic strategies for NF1.

\section{ACKNOWLEDGEMENTS}

This work was supported by grants from the National Cancer Institute of Canada (NCIC; to AG) and National Institute of Health (NIH) grant no. GM49360 (to DG). DG is also supported by Schnuck Markets Inc. AG is a Medical Research Council of Canada Clinician Scientist. MMF is a Terry Fox Research Fellow of the NCIC, supported by funds raised in the Terry Fox Run.

\section{REFERENCES}

1. von Recklinghausen FD. Über die multiplen Fibrome der Haut und ihre Beziehung zu den multiplen Neuromen. Berlin, Hirschwald, 1882.

2. Riccardi VM, Eichner JE. Neurofibromatosis: Phenotype, Natural History, and Pathogenesis. Baltimore, MD, Johns Hopkins University Press, 1992.

3. Trofatter JA, MacCollin MM, Rutter JL, et al. A novel moesin-, ezrin-, radixin-like gene is a candidate for the neurofibromatosis 2 tumor suppressor. Cell 1993; 72: 791-800.

4. Rouleau GA, Merel P, Lutchman M, et al. Alteration in a new gene encoding a putative membrane organizing protein causes neurofibromatosis type 2 . Nature $1993 ; 363: 515-521$.

5. Evans DGR, Huson SM, Donnai D, et al. A clinical study of type 2 neurofibromatosis. Q J Med 1992; 84: 603-618.

6. Tibbles JAR, Cohen MM. The Proteus syndrome: the Elephant Man diagnosed. Br Med J 1986; 293: 683-685.

7. Lott IT, Richardson Jr EP. Neuropathological findings and the biology of neurofibromatosis. Adv Neurol 1981; 29: 23-32.

8. Gutmann DH, Collins FS. von Recklinghausen neurofibromatosis. In: Scriver CR, Beaudet AL, Sly WS, Valle D, eds. von Recklinghausen Neurofibromatosis. New York, McGraw-Hill, 1995: 677-696.

9. Burwell RG, James NJ, Johnston DI. Cafe-au-lait spots in schoolchildren. Arch Dis Child 1982; 57: 631-632.

10. Stumpf S, Alksne JF, Annegers JF et al. Neurofibromatosis. Conference statement. National Institutes of Health Consensus Development Conference. Arch Neurol 1988; 45: 575-578.

11. Huson SM. Neurofibromatosis 1: A clinical and genetic overview. In: Huson SM, Hughes RAC, eds. Neurofibromatosis 1: A clinical and genetic overview. London, Chapman and Hall, 1994: 160-203.

12. Grifa A, Piemontese MR, Melchionda S, et al. Screening of neurofibromatosis type 1 gene: identification of a large deletion and of an intronic variant. Clin Genet 1995; 47: 281-284.

13. Sorensen SA, Mulvihill JJ, Nielsen A. Long-term follow-up of von Recklinghausen neurofibromatosis. Survival and malignant neoplasms. N Engl J Med 1986; 314: 1010-1015.

14. Zoller M, Rembeck B, Akesson HO, Angervall L. Life expectancy, mortality and prognostic factors in neurofibromatosis type 1 . A twelve-year follow-up of an epidemiological study in Göteborg, Sweden. Acta Derm Venereol 1995; 75: 136-140.

15. Riccardi VM. Von Recklinghausen neurofibromatosis. N Engl J Med 1981; 305: 1617-1627.

16. Shannon KM, O'Connell P, Martin GA, et al. Loss of the normal $\mathrm{NF} 1$ allele from the bone marrow of children with type 1 neurofibromatosis and malignant myeloid disorders. N Engl J Med 1994; 330: 597-601.

17. Mulvihill JJ. Malignancy: epidemiologically associated cancers. In: Huson SM, Hughes RAC, eds. Malignancy: Epidemiologically Associated Cancers. London, Chapman \& Hall Medical, 1994: 305-315.

18. Marchuk DA, Saulino AM, Tavakkol R, et al. cDNA cloning of the type 1 neurofibromatosis gene: complete sequence of the $N F 1$ gene product. Genomics 1991; 11: 931-940. 
19. Preiser SA, Davenport CB. Multiple neurofibromatosis (von Recklinghausen disease) and its inheritance. Am J Med Sci 1918; 156: 507.

20. Crowe F. A Clinical, Pathological and Genetic Study of Multiple Neurofibromatosis. Springfield, IL, C.C. Thomas, 1956.

21. Borberg A. Clinical and genetic investigations into tuberous sclerosis and Recklinghausen's neurofibromatosis. Acta Psychiatr Neurol (Suppl.) 1951; 71: 1-239.

22. Riccardi VM, Lewis RA. Penetrance of von Recklinghausen neurofibromatosis: a distinction between predecessors and descendents. Am J Hum Genet 1988; 42: 284-289.

23. Sergeyev AS. On the mutation rate of neurofibromatosis. Humangenetik 1975; 28: 129-138.

24. Carey JC, Baty BJ, Johnson JP, et al. The genetic aspects of neurofibromatosis. Ann N Y Acad Sci 1986; 486: 45-56.

25. Monaco AP, Neve RL, Colletti-Feener C, et al. Isolation of candidate cDNAs for portions of the Duschenne muscular dystrophy gene. Nature 1986; 323: 646-650.

26. Richards FM, Payne SJ, Zbar B, et al. Molecular analysis of de novo germline mutations in the von Hippel-Lindau disease gene. Hum Mol Genet 1995; 4: 2139-2143.

27. Rodenhiser DI, Coulter-Mackie MB, Singh SM. Evidence of DNA methylation in the neurofibromatosis type 1 (NF1) gene region of 17q11.2. Hum Mol Genet 1993; 2: 439-444.

28. Colman SD, Williams CA, Wallace MR. Benign neurofibromas in type 1 neurofibromatosis (NFI) show somatic deletions of the NFI gene. Nat Genet 1995; 11: 90-92.

29. Jadayel D, Fain P, Upadhyaya M, et al. Paternal origin of new mutations in von Recklinghausen neurofibromatosis. Nature 1990; 343: 558-559.

30. Hall JG. Genomic imprinting: review and relevance to human diseases. Am J Hum Genet 1990; 46: 857-873.

31. Stephens K, Kayes L, Riccardi VM, et al. Preferential mutation of the neurofibromatosis type 1 gene in paternally derived chromosomes. Hum Genet 1992; 88: 279-282.

32. Monk M, Boubelik M, Lehnert S. Temporal and regional changes in DNA methylation in the embryonic, extraembryonic and germ line lineages during mouse embryo development. Development 1987; 99: 371-382.

33. Driscoll DJ, Migeon BR. Sex difference in methylation of singlecopy genes in human meiotic germ cells: implications for $\mathrm{X}$ chromosome inactivation, parental imprinting, and origin of CpG mutations. Somat Cell Mol Genet 1990; 16: 267-282.

34. Miller M, Hall JG. Possible maternal effect on severity of neurofibromatosis. Lancet 1978; 2: 1071-1073.

35. Easton DF, Ponder MA, Huson SM, Ponder BAJ. An analysis of variation in expression of neurofibromatosis (NF) type 1 (NF1): evidence for modifying genes. Am J Hum Genet 1993; 53: 305-313.

36. Sarfarazi M, Huson SM, Edwards JH. An exclusion map for von Recklinghausen neurofibromatosis. J Med Genet 1987; 24: 515-520.

37. Barker D, Wright E, Nguyen K, et al. Gene for von Recklinghausen neurofibromatosis is in the pericentromeric region of chromosome 17. Science 1987; 236: 1100-1102.

38. Stephens K, Green P, Riccardi VM, et al. Genetic analysis of eight loci tightly linked to neurofibromatosis 1 . Am J Hum Genet $1989 ; 44: 13-19$

39. Goldgar DE, Green P, Parry DM, Mulvihill JJ. Multipoint linkage analysis in neurofibromatosis type 1: an international collaboration. Am J Hum Genet 1989; 44: 6-12.

40. Ledbetter DH, Rich DC, O'Connell P, Leppert M, Carey JC. Precise localization of $N F 1$ to $17 \mathrm{q} 11.2$ by balanced translocation. Am J Med Genet 1989; 44: 20-24.

41. Schmidt MA, Michels VV, Dewald GW. Cases of neurofibromatosis with rearrangements of chromosome 17 involving band 17q11.2. Am J Med Genet 1987; 28: 771-777.

42. O'Connell P, Leach R, Cawthon RM, et al. Two NFI translocations map within a 600-kilobase segment of $17 q 11.2$. Science 1989; 244: 1087-1088.

43. Fountain JW, Wallace MR, Bruce MA, et al. Physical mapping of a translocation breakpoint in neurofibromatosis. Science 1989; 244: 1085-1087.
44. O’Connell P, Viskochil D, Buchberg AM, et al. The human homolog of murine Evi-2 lies between two von Recklinghausen neurofibromatosis translocations. Genomics 1990; 7: 547-554.

45. Cawthon RM, Anderson LB, Buchberg AM, et al. cDNA sequence and genomic structure of $E V I 2 B$, a gene lying within an intron of the neurofibromatosis type 1 gene. Genomics 1991; 9: 446-460.

46. Viskochil D, Cawthon R, O'Connell $P$, et al. The gene encoding the oligodendrocyte-myelin glycoprotein is embedded within the neurofibromatosis type 1 gene. Mol Cell Biol 1991; 11: 906-912.

47. Xu GF, O'Connell P, Viskochil D, et al. The neurofibromatosis type 1 gene encodes a protein related to GAP. Cell 1990; 62: 599-608.

48. Viskochil D, Buchberg AM, Xu G, et al. Deletions and a translocation interrupt a cloned gene at the neurofibromatosis type 1 locus. Cell 1990; 62: 187-192.

49. Wallace MR, Marchuk DA, Andersen LB, et al. Type 1 neurofibromatosis gene: identification of a large transcript disrupted in three NF1 patients. Science 1990; 249: 181-186.

50. Li Y, O'Connell P, Breidenbach HH, et al. Genomic organization of the neurofibromatosis I gene $(N F I)$. Genomics 1995; 25: 9-18.

51. Hajra A, Martin-Gallardo A, Tarle SA, Freedman M, Wilson-Gunn $\mathrm{S}$, et al. DNA sequences in the promoter region of the $N F I$ gene are highly conserved between human and mouse. Genomics 1994; 21 : 649-652.

52. Viskochil D, White R, Cawthon R. The neurofibromatosis type 1 gene. Ann Rev Neurosci 1993; 16: 183-205.

53. DeClue JE, Cohen BD, Lowy DR. Identification and characterization of the neurofibromatosis typel protein product. Proc Natl Acad Sci U S A 1991; 88: 9914-9918.

54. Gutmann DH, Wood DL, Collins FS. Identification of the neurofibromatosis type 1 gene product. Proc Natl Acad Sci U S A 1991; 88: 9658-9662

55. Daston MM, Scrable $H$, Nordlund $M$, et al. The protein product of the neurofibromatosis type 1 gene is expressed at highest abundance in neurons, Schwann cells, and oligodendrocytes. Neuron 1992; 8: 415-428.

56. Gutmann DH, Geist RT, Wright DE, Snider WD. Expression of the neurofibromatosis 1 (NF1) isoforms in developing and adult rat tissues. Cell Growth Differ 1995; 6: 315-323.

57. Andersen LB, Ballester R, Marchuk DA, et al. A conserved alternative splice in the von Recklinghausen neurofibromatosis (NFI) gene produces two neurofibromin isoforms, both of which have GTPase-activating protein activity. Mol Cell Biol 1993; 13: 487-495.

58. Bernards A, Haase VH, Murthy AE, et al. Complete human NFI cDNA sequence: two alternatively spliced mRNAs and absence of expression in a neuroblastoma line. DNA Cell Biol 1992; 11: 727-734.

59. Teinturier C, Danglot G, Slim R, et al. The neurofibromatosis 1 gene transcripts expressed in peripheral nerve and neurofibromas bear the additional exon located in the GAP domain. Biochem Biophys Res Commun 1992; 188: 851-857.

60. Gutmann DH, Andersen LB, Cole JL, Swaroop M, Collins FS. An alternatively-spliced mRNA in the carboxy terminus of the neurofibromatosis type $1(N F I)$ gene is expressed in muscle. Hum Mol Genet 1993; 2: 989-992.

61. Gutmann DH, Geist RT, Rose K, Wright DE. Expression of two new protein isoforms of the neurofibromatosis type 1 gene product, neurofibromin, in muscle tissues. Dev Dyn 1995; 202: 302-311.

62. Danglot G, Regnier V, Fauvet D, et al. Neurofibromatosis $1(N F I)$ mRNAs expressed in the central nervous system are differentially spliced in the 5' part of the gene. Hum Mol Genet 1995; 4: 915-920.

63. Geist RT, Gutmann DH. Expression of a developmentally-regulated neuron-specific isoform of the neurofibromatosis I (NFI) gene. Neurosci Lett 1996; 211 : 85-88.

64. Platten M, Giordano MJ, Dirven CMF, Gutmann DH, Louis DN. Up-regulation of specific $N F l$ gene transcripts in sporadic pilocytic astrocytomas. Am J Pathol 1996; 149: 621-627.

65. Buchberg AM, Cleveland LS, Jenkins NA, Copeland NG. Sequence homology shared by neurofibromatosis type-1 gene and $I R A-I$ and $I R A-2$ negative regulators of the RAS cyclic AMP pathway. Nature 1990; 347: 291-294. 
66. Ahmadian MR, Wiesmuller L, Lautwein A, Bischoff FR, Wittinghofer A. Structural differences in the minimal catalytic domains of the GTPase-activating proteins $\mathrm{p} 120^{\mathrm{GAP}}$ and neurofibromin. J Biol Chem 1996; 271 : 16409-16415

67. Cullen PJ, Hsuan JJ, Truong $\mathrm{O}$, et al. Identification of a specific Ins $(1,3,4,5)$ P4-binding protein as a member of the GAP1 family. Nature 1995; 376: 527-530.

68. Bollag G, McCormick F. Differential regulation of rasGAP and neurofibromatosis gene product activities. Nature 1991; 351: 576-579.

69. Downward J. Regulation of $\mathrm{p} 21$ ras by GTPase activating proteins and guanine nucleotide exchange proteins. Curr Opin Genet Dev 1992; 2: 13-18.

70. Downward J. Regulatory mechanisms for ras proteins. Bioessays 1992; 14: 177-184

71. McCormick F. Signal transduction. How receptors turn Ras on. Nature 1993; 363: 15-16.

72. McCormick F. Ras signaling and NF1. Curr Opin Genet Dev 1995; 5: $51-55$.

73. Guha A, Lau N, Gutmann D, et al. Ras-GTP levels are elevated in human NF1 peripheral nerve tumours. Oncogene 1996; 12: 507-513.

74. Maekawa M, Li S, Iwamatsu A, et al. A novel mammalian Ras GTPase-activating protein which has phospholipid-binding and Btk homology regions. Mol Cell Biol 1994; 14: 6879-6885.

75. Rozakis-Adcock M, Fernley R, Wade J, Pawson T, Bowtell D. The $\mathrm{SH} 2$ and $\mathrm{SH} 3$ domains of mammalian Grb2 couple the EGF receptor to the Ras activator mSos I. Nature $1993 ; 363: 83-85$.

76. Lowenstein EJ, Daly RJ, Batzer AG, et al. The SH2 and SH3 domain-containing protein GRB2 links receptors tyrosine kinases to ras signaling. Cell 1992; 70: 431-442.

77. Buday L, Downward J. Epidermal growth factor regulates $\mathrm{p} 21$ ras through the formation of a complex of receptor. Grb2 adapter protein, and Sos nucleotide exchange factor. Cell 1993; 73:611-620.

78. Chardin P, Camonis JH, Gale NW, et al. Human Sos 1: a guanine nucleotide exchange factor for Ras that binds to GRB2. Science 1993; 260: 1338-1343.

79. Egan SE, Giddings BW, Brooks MW, et al. Association of Sos Ras exchange protein with Grb2 is implicated in tyrosine kinase signal transduction and transformation. Nature 1993; 363: 45-51.

80. Li W, Nishimura R, Kashishian A, et al. A new function for a phosphotyrosine phosphatase: linking GRB2-Sos to a receptor tyrosine kinase. Mol Cell Biol 1994; 14: 509- 517.

81. Rozakis-Adcock M, McGlade J, Mbamalu G, et al. Association of the Shc and Grb2/Sem5 SH2-containing proteins is implicated in activation of the Ras pathway by tyrosine kinases. Nature 1992; 360: 689-692.

82. Bos JL. Ras oncogenes in human cancers: a review. Cancer Res 1989; 49: 4682-4689.

83. Cantley LC, Auger KR, Carpenter C, et al. Oncogenes and signal transduction. Cell 1991; 64: 281-302.

84. Martin GA, Viskochil D, Bollag G, et al. The GAP-related domain of the neurofibromatosis type 1 gene product interacts with ras $\mathrm{p} 21$. Cell 1990; 63: 843-849.

85. Ballester R, Marchuk D, Boguski M, et al. The NFI locus encodes a protein functionally related to mammalian GAP and yeast IRA proteins. Cell 1990; 63: 851-859.

86. Xu GF, Lin B, Tanaka K, et al. The catalytic domain of the neurofibromatosis type I gene product stimulates ras GTPase and complements ira mutants of S. cerevisiae. Cell 1990; 63: 835-841.

87. Nur-E-Kamal MSA, Varga M, Maruta $H$. The GTPase-activating NF1 fragment of 91 amino acids reverses v-Ha-Ras-induced malignant phenotype. J Biol Chem 1993; 268: 22331-22337.

88. Basu TN, Gutmann DH, Fletcher JA, et al. Aberrant regulation of ras proteins in malignant tumour cells from type 1 neurofibromatosis patients. Nature 1992; 356: 713-715

89. DeClue JE, Papageorge AG, Fletcher JA, et al. Abnormal regulation of mammalian $21^{\text {ras }}$ contributes to malignant tumor growth in von Recklinghausen (type 1) neurofibromatosis. Cell 1992; 69: 265-273

90. Johnson MR, DeClue JE, Felzmann S, et al. Neurofibromin can inhibit Ras-dependent growth by a mechanism independent of its GTPase-accelerating function. Mol Cell Biol 1994; 14: 641645 .
91. Nakafuku M, Nagamine M, Ohtoshi A, et al. Suppression of oncogenic Ras by mutant neurofibromatosis type 1 genes with single amino acid substitutions. Proc Natl Acad Sci U S A 1993; 90: 6706-6710.

92. Feldkamp MM, Lau N, Provias JP, Guha A. Acute presentation of a neurogenic sarcoma in a patient with neurofibromatosis type 1: A pathologic and molecular explanation. J Neurosurg 1996; 84: 867-873

93. Johnson MR, Look AT, DeClue JE, Valentine MB, Lowy DR. Inactivation of the $\mathrm{NFI}$ gene in human melanoma and neuroblastoma cell lines without impaired regulation of GTP•Ras. Proc Natl Acad Sci U S A 1993; 90: 5539-5543.

94. Li Y, White R. Suppression of a human colon cancer cell line by introduction of an exogenous NFI gene. Cancer Res 1996; 56: 2872-2876.

95. Gutmann DH. Tumor suppressor genes as negative growth regulators in development and differentiation. Int J Dev Biol 1995; 39: 895-907.

96. Gregory PE, Gutmann DH, Mitchell A, et al. The neurofibromatosis type 1 gene product (neurofibromin) associates with microtubules. Somat Cell Mol Genet 1993; 19: 265-274.

97. Bollag G, McCormick F, Clark R. Characterization of full-length neurofibromin: tubulin inhibits Ras GAP activity. EMBO J 1993; 12: 1923-1927.

98. Boyer MJ, Gutmann DH, Collins FS, Bar-Sagi D. Crosslinking of the surface immunoglobulin receptor in B lymphocytes induces a redistribution of neurofibromin but not p120-GAP. Oncogene 1994; 9; 349-357.

99. Izawa I, Tamaki N, Saya H. Phosphorylation of neurofibromatosis type 1 gene product (neurofibromin) by cAMP-dependent protein kinase. FEBS Lett 1996; 382: 53-59.

100. Gutmann DH, Collins FS. The neurofibromatosis type I gene and its protein product, neurofibromin. Neuron 1993; 10: 335-343.

101. Gutmann DH, Mahadeo DK, Giordano M, Silbergeld D, Guha A. Increased neurofibromatosis 1 gene expression in astrocytic tumors: positive regulation by $\mathrm{p} 21$-ras. Oncogene 1996; 12: $2121-2127$

102. Giordano MJ, Mahadeo DK, He YY, et al. Increased expression of the neurofibromatosis 1 (NF1) gene product, neurofibromin, in astrocytes in response to cerebral ischemia. J Neurosci Res 1996; 43: 246-253.

103. Knudson Jr AG. Mutation and cancer: statistical study of retinoblastoma. Proc Natl Acad Sci U S A 1971; 68: 820-823

104. Xu W, Mulligan LM, Ponder MA,et al. Loss of NFl alleles in phaeochromocytomas from patients with type I neurofibromatosis. Genes Chromosomes Cancer 1992; 4: 337-342.

105. Gutmann DH, Cole JL, Stone WJ, Ponder BAJ, Collins FS. Loss of neurofibromin in adrenal gland tumors from patients with neurofibromatosis type 1. Genes Chromosomes Cancer 1994; 10: $55-58$.

106. Sawada $\mathrm{Si}$, Florell S, Purandare SM, et al. Identification of NFI mutations in both alleles of a dermal neurofibroma. Nat Genet 1996; 14: 110-112.

107. Takahashi K, Suzuki H, Hatori M, et al. Reduced expression of neurofibromin in the soft tissue tumours obtained from patients with neurofibromatosis type I. Clin Sci 1995; 88: 581-585.

108. Legius E, Marchuk DA, Collins FS, Glover TW. Somatic deletion of the neurofibromatosis type 1 gene in a neurofibrosarcoma supports a tumour suppressor gene hypothesis. Nat Genet 1993; 3: 122-126.

109. Jacks T, Shih TS, Schmitt EM, et al. Tumour predisposition in mice heterozygous for a targeted mutation in Nfl. Nat Genet 1994; 7: 353-361.

110. Brannan Cl, Perkins AS, Vogel KS, et al. Targeted disruption of the neurofibromatosis type-1 gene leads to developmental abnormalities in heart and various neural crest-derived tissues. Genes Dev 1994; 8: 1019-1029.

111. Kirby ML, Gale TF, Stewart DE. Neural crest cells contribute to aorticopulmonary septation. Science 1983; 220: 1059-1061

112. Vogel KS, Brannan CI, Jenkins NA, Copeland NG, Parada LF. Loss of neurofibromin results in neurotrophin-independent survival of embryonic sensory and sympathetic neurons. Cell 1995; 82: 733-742. 
113. Borasio GD, John J, Wittinghofer A, et al. ras $\mathrm{p} 21$ protein promotes survival and fiber outgrowth of cultured embryonic neurons. Neuron 1989; 2: 1087-1096.

114. Kim HA, Rosenbaum T, Marchionni MA, Ratner N, DeClue JE. Schwann cells from neurofibromin deficient mice exhibit activation of $\mathrm{p} 21$ ras, inhibition of cell proliferation and morphological changes. Oncogene 1995; 11: 325-335.

115. Rosenbaum C, Krasnoselski AL, Marchionni MA, Brackenbury RW, Ratner N. Neuregulins and neu/erbB2 are required for response of Schwann cells to multiple growth factors. J Neurochem 1996; 66: $\mathrm{S47}$.

116. Johnson MD, Kamso-Pratt J, Federspiel CF, Whetsell Jr. WO. Mast cell and lymphoreticular infiltrates in neurofibromas. Comparison with nerve sheath tumors. Arch Pathol Lab Med 1989; 113: 1263-1270.

117. Ducatman BS, Scheithauer BW, Piepgras DG, Reiman HM, Ilstrup DM. Malignant peripheral nerve sheath tumors. A clinicopathologic study of 120 cases. Cancer 1986; 57: 2006-2021.

118. Birch R. Peripheral nerve tumors. In: Dyck PJ, Thomas RK, eds. Peripheral Nerve Tumors. Philadelphia, W.B. Saunders, 1993: 1623-1640.

119. Enneking W. Musculo-skeletal Tumor Surgery. Edinburgh, Churchill Livingstone, 1983.

120. Castresana JS, Barrios C, Gomez L, Kreicbergs A. No association between $c$-myc amplification and TP53 mutation in sarcoma tumorigenesis. Cancer Genet Cytogenet 1994; 76: 47-49.

121. Andreassen A, Oyjord T, Hovig E, et al. p53 abnormalities in different subtypes of human sarcomas. Cancer Res 1993; 53: 468-471.

122. Lothe RA, Slettan A, Saeter G, Bet al. Alterations at chromosome 17 loci in peripheral nerve sheath tumors. J Neuropathol Exp Neurol 1995; 54: 65-73

123. Cordon-Cardo C, Latres E, Drobnjak M, et al. Molecular abnormalities of $m d m 2$ and $p 53$ genes in adult soft tissue sarcomas. Cancer Res 1994; 54: 794-799.

124. Legius E, Dierick H, Wu R, et al. TP53 mutations are frequent in malignant NF1 tumors. Genes Chromosomes Cancer 1994; 10: 250-255.

125. Menon AG, Anderson KM, Riccardi VM, et al. Chromosome 17p deletions and $\mathrm{p} 53$ gene mutations associated with the formation of malignant neurofibrosarcomas in von Recklinghausen neurofibromatosis. Proc Natl Acad Sci U S A 1990; 87: 5435 5439.

126. Friend SH, Horowitz JM, Gerber MR, et al. Deletions of a DNA sequence in retinoblastomas and mesenchymal tumors: organization of the sequence and its encoded protein. Proc Natl Acad Sci U S A 1987; 84: 9059-9063.

127. Wunder JS, Czitrom AA, Kandel R, Andrulis IL. Analysis of alterations in the retinoblastoma gene and tumor grade in bone and soft-tissue sarcomas. J Natl Cancer Inst 1991; 83: 194-200.
128. Cance WG, Brennan MF, Dudas ME, Huang CM, Cordon-Cardo C. Altered expression of the retinoblastosis gene product in human sarcomas. N Engl J Med 1990; 323: 1457-1462.

129. Jhanwar SC, Chen Q, Li FP, Brennan MF, Woodruff JM. Cytogenetic analysis of soft tissue sarcomas. Recurrent chromosome abnormalities in malignant peripheral nerve sheath tumors (MPNST). Cancer Genet Cytogenet 1994; 78: 138-I44.

130. Ottini L, Esposito DL, Richetta A, et al. Alterations of microsatellites in neurofibromas of von Recklinghausen's disease. Cancer Res 1995; 55: 5677-5680.

131. Uchida T, Wang C, Wada C, et al. Microsatellite instability in transitional cell carcinoma of the urinary tract and its relationship to clinicopathological variables and smoking. Int $\mathbf{J}$ Cancer 1996; 69: 142-145.

132. Zhu J, Guo SZ, Beggs AH, et al. Microsatellite instability analysis of primary human brain tumors. Oncogene 1996; 12: 1417 1423.

133. Upadhyaya $M$, Shen $M$, Cherryson A, et al. Analysis of mutations at the neurofibromatosis I (NFI) locus. Hum Mol Genet 1992; 1: 735-740.

134. Lazaro C, Kruyer H, Gaona A, Estivill X. Two further cases of mutation R1947X in the NF1 gene: screening for a relatively common recurrent mutation. Hum Genet 1995; 96: 361-363.

135. Hofman KJ, Boehm CD. Familial neurofibromatosis type 1: clinical experience with DNA testing. J Pediatr 1992; 120: 394398.

136. Dublin S, Riccardi VM, Stephens K. Methods for rapid detection of a recurrent nonsense mutation and documentation of phenotypic features in neurofibromatosis type I patients. Hum Mutat 1995; 5: 81-85.

137. Gasparini P, D'Agruma L, Pio de Cillis G, et al. Scanning the first part of the neurofibromatosis type 1 gene by RNA- SSCP: identification of three novel mutations and of two new polymorphisms. Hum Genet 1996; 97: 492-495.

138. Gibbs JB, Oliff A, Kohl NE. Farnesyltransferase inhibitors: Ras research yields a potential cancer therapeutic. Cell 1994; 77 $175-178$.

139. Hancock JF, Paterson H, Marshall CJ. A polybasic domain or palmitoylation is required in addition to the CAAX motif to localize p21ras to the plasma membrane. Cell 1990; 63: 133139.

140. Kohl NE, Omer CA, Conner MW, et al. Inhibition of farnesyltransferase induces regression of mammary and salivary carcinomas in ras transgenic mice. Nat Med 1995; 1: 792-797.

141. Yan N, Ricca C, Fletcher J, et al. Farnesyltransferase inhibitors block the neurofibromatosis type I (NFI) malignant phenotype. Cancer Res 1995; 55: 3569-3575.

142. Pang L, Sawada T, Decker SJ, Saltiel AR. Inhibition of MAP kinase kinase blocks the differentiation of $P C-12$ cells induced by nerve growth factor. J Biol Chem 1995; 270: 13585-13588. 